\title{
Faktor Individu Tenaga Kesehatan Puskesmas dalam Kesiapsiagaan Bencana Banjir Bengawan Solo, Bojonegoro
}

\section{Individual factors of health workers primary health center in preparedness flood disaster Bengawan Solo, Bojonegoro}

\author{
Ulfah Mu'amarotul Hikmah ${ }^{1 *}$, Shinta Febrianty², Setya Haksama ${ }^{3}$
}

\begin{abstract}
ABSTRAK
Latar Belakang: Kesiapsiagaan adalah serangkaian kegiatan yang dilakukan untuk mengantisipasi bencana melalui pengorganisasian. Pusat kesehatan masyarakat (Puskesmas) sebagai fasilitas kesehatan pertama atau dasar dalam suatu daerah harus memiliki sumberdaya dan kompetensi yang cukup dalam kesiapsiagaan bencana, karena terdapat banyak faktor yang dapat mempengaruhi kesiapsiagaan puskesmas terutama pada tenaga kesehatannya, meliputi usia; lama kerja; pengalaman bencana sebelumnya; pengalaman di tempat pengungsian; peraturan diri; pelayanan kesehatan; sarana prasarana; dan lainnya.

Tujuan: Penelitian ini bertujuan untuk menganalisis faktor individu tenaga kesehatan yang mempengaruhi kesiapsiagaan puskesmas dalam merespon bencana banjir sungai Bengawan Solo di Kabupaten Bojonegoro yakni Puskesmas Kanor.

Metode: Desain penelitian adalah observasional analitik dengan pendekatan kuantitatif, serta menggunakan rancang bangun penelitian cross-sectional. Sampel penelitian sebanyak 51 orang tenaga kesehatan Puskesmas Kanor. Data primer penelitian diambil menggunakan kuesioner wawancara. Data penelitian dianalisis secara kuantitatif dengan pengolahan data yang dilakukan secara computerize. Uji signifikansi setiap variabel dilakukan dengan menggunakan uji regresi logistik ordinal melalui bantuan aplikasi SPSS.

Hasil: Hasil nilai signifikansi uji regresi logistik ordinal faktor individu dan kesiapsiagaan yakni: usia (AOR 4,11; 95\% CI=1,27-13,35), tingkat pendidikan (AOR 14,23; 95\% CI=1,67-121,3), lama bekerja (AOR 3,12; $95 \% \mathrm{CI}=0,90-10,76$ ), pengalaman bencana sebelumnya (AOR 1,14; $95 \% \mathrm{CI}=0,16-2,46)$, pelatihan (AOR 2,45; 95\% CI=0,74-8,07), dan pengetahuan (AOR 2,00; 95\% CI=0,65-6,15).

Kesimpulan: Faktor individu tenaga kesehatan meliputi usia dan tingkat pendidikan memiliki pengaruh terhadap kesiapsiagaan puskesmas dalam menghadapi bencana. Faktor individu lain yang meliputi lama bekerja, pengetahuan, pelatihan tentang manajemen bencana, dan pengalaman bencana sebelumnya tidak memiliki pengaruh terhadap kesiapsiagaan puskesmas dalam menghadapi bencana banjir Bengawan Solo.
\end{abstract}

Kata kunci: pusat kesehatan masyarakat; kesiapsiagaan; manajemen bencana; banjir

\section{ABSTRACT}

Background: Preparedness is a series of activities carried out to anticipate disasters through organizing. The community health center (Puskesmas) as the first or basic health facility in an area must have sufficient resources and competence in disaster preparedness, because there are many factors that can affect the preparedness of the puskesmas, especially its health personnel, including age; length of working; previous disaster experience; experience in refugee camps; self-regulation; health services; infrastructure; and others.

Objectives: This study aims to analyze the individual factors of health workers that affect the preparedness of the puskesmas in responding to the flood disaster of the Bengawan Solo river in Bojonegoro Regency, namely the Kanor Health Center.

Methods: The research design is analytical observational with a quantitative approach and uses a crosssectional research design. The research sample was 51 health workers from Kanor Health Center. The primary data of the study were taken using an interview questionnaire. The research data were analyzed quantitatively 
with computerized data processing. The significance test of each variable was carried out using an ordinal logistic regression test with the help of the SPSS application.

Results: The results of the significance value of the ordinal logistic regression test for individual factors and preparedness, namely: age (AOR 4,11; 95\% CI=1,27-13,35), education level (AOR 14,23; 95\%CI=1,67-121,3), length of work (AOR 3,12; 95\%CI=0,90-10,76), previous disaster experience (AOR 1,14; 95\%CI=0,16-2,46), training (AOR 2,45; 95\% CI=0,74-8,07), knowledge (AOR 2,00; 95\%CI=0,65-6,15).

Conclusions: Individual factors for health workers including age and level of education have an influence on the preparedness of puskesmas in facing disasters. Other individual factors, which include the length of work, knowledge, training on disaster management, and previous disaster experiences have no influence on the preparedness of the puskesmas in dealing with the Bengawan Solo flood disaster.

Keywords: public health center; preparedness; disaster management; flood

\author{
*Koresponden: \\ ulfah.muamarotul@gmail.com \\ Ulfah Mu'amarotul Hikmah \\ ${ }^{1}$ Departemen Administrasi dan Kebijakan Kesehatan, Fakultas Kesehatan Masyarakat, Universitas Airlangga, \\ Kampus C Mulyorejo, 60115, Surabaya, Jawa Timur, Indonesia
}

\title{
PENDAHULUAN
}

Menjadi salah satu negara tropis di dunia, Indonesia merupakan negara yang memiliki risiko tinggi terhadap kejadian bencana. Mengingat, terdapat dua musim yang dimiliki oleh Indonesia yaitu musim panas dan hujan. Indonesia merupakan salah satu negara yang rawan mengalami banjir berdasarkan karakteristik geografis dan geologi. Dari sekitar 500 sungai di Indonesia, sebanyak 30\% melalui kawasan dengan penduduk yang padat (Wahyudi et al., 2019). Sungai yang melewati kawasan padat penduduk dapat memicu permasalahan yang menyebabkan kualitas air menjadi berkurang. Hal itu disebabkan adanya sampah, limbah domestik, dan limbah industri (Yustiani et al., 2019). Tidak hanya itu, kawasan padat juga dapat berakibat pada berkurangnya ruang peresapan air, terutama di Daerah Aliran Sungai (DAS). Berkurangnya ruang peresapan berdampak pada berkurangnya cadangan air tanah terutama di wilayah perkotaan dan permukiman padat bagian hilir (Purwantara, 2015).

Terlebih di musim penghujan, curah hujan dan intensitas hujan yang tinggi serta pengaruh pasang sungai, menjadi salah satu penyebab utama banjir di wilayah pemukiman padat. Pada saat terjadi kelebihan air di DAS, air yang berada pada sistem sub DAS tidak dapat mengalir keluar karena tertahan oleh air sungai yang sedang pasang, sehingga kelebihan air tersebut dapat menggenangi wilayah sekitarnya (Dinar et al., 2019).

Banjir merupakan kejadian bencana yang masuk dalam salah satu kelompok hidrometeorologi. Kondisi alam seperti geografis, topografis, dan geometri alur sungai dapat menjadi penyebab terjadinya banjir. Selain itu, banjir juga disebabkan oleh peristiwa alam yang dinamis seperti tingginya curah hujan, pembendungan dari laut/pasang pada sungai induk, muka tanah yang turun dan adanya sedimentasi sehingga mengakibatkan pendangkalan, serta aktivitas manusia yang dinamis pula. Aktivitas manusia tersebut seperti penggunaan lahan yang tidak semestinya di daerah rawan banjir, misalnya dengan mendirikan pemukiman di tepi sungai, insfrastruktur yang kurang dalam pengendalian banjir, penurunan permukaan tanah dan pemanasan global yang mengakibatkan permukaan air laut naik. (Sastrodiharjo, 2012). Studi dari Irvani dan Indra Gunawan tahun 2015, debit banjir dapat meningkat pada wilayah dengan permukiman yang padat, dikarenakan aliran air menjadi lebih lambat pada saat hujan dan diperparah adanya penimbunan daerah resapan serta genangan air seperti rawa (Irvani dan Gunawan, 2015).

Pada tahun 2019 lalu, Indonesia dilanda bencana banjir akibat dari meluapnya sungai Bengawan Solo yang menyebabkan beberapa kawasan di Kabupaten Bojonegoro terendam. Badan Nasional Penangan Bencana melalui platformnya terkait Data Informasi Bencana Indonesia (DIBI) 2019, menyebutkan bahwa sungai yang memiliki intensitas cenderung meluap pada tahun 2019 adalah sungai Bengawan Solo (BNPB, 2019). Data tersebut sejalan dengan penelitian Sulaeman et al, 2017 yang memprediksi besaran luasan genangan banjir pada debit kala ulang 2, 5, 10, 20, 50, dan 100 tahun menyebutkan, bahwa genangan banjir untuk seluruh Kabupaten Bojonegoro memberikan dampak pada masyarakat seluruh wilayahnya, yaitu sekitar 160.542 jiwa terancam banjir (Sulaeman et al., 2017). Hal tersebut sejalan dengan laporan BPBD Kabupaten Bojonegoro terkait banyaknya kejadian banjir beserta penyebabnya. Berdasarkan data tersebut, total kejadian banjir di Kabupaten Bojonegoro pada tahun 2017 hingga 2018 mengalami kenaikan sebesar 100\% (BNPB, 2019). Total kejadian banjir tersebut yakni jumlah bencana banjir yang terjadi di wilayah Bojonegoro selama rentang waktu 20172018. 
Pada bulan Maret tahun 2019, bencana di Indonesia masih didominasi oleh hidrometeorologi khususnya banjir. Kabupaten Bojonegoro menjadi salah satu daerah di Indonesia yang masih rawan terhadap bencana banjir meskipun telah mengalami penurunan dari tahun 2018 ke 2019. Tahun 2017, terdapat sebanyak 4 kejadian banjir di Bojonegoro, kemudian meningkat di tahun 2018 sebanyak 8 kejadian banjir, dan menurun kembali tahun 2019 menjadi 5 kejadian banjir (BNPB, 2019).

Sebanyak 36 puskesmas di Kabupaten Bojonegoro memiliki kerentanan pada bencana banjir akibat luapan sungai Bengawan Solo. Berdasarkan data kejadian bencana BPBD Kabupaten Bojonegoro 2019, sejumlah kecamatan yang ada di Kabupaten Bojonegoro telah terdampak akibat bencana banjir dari luapan Sungai Bengawan Solo. Diantaranya adalah Kecamatan Kanor, Balen, Baureno, Bojonegoro, Kapas, dan Trucuk. Sedangkan angka kejadian bencana banjir Bengawan Solo yang tertinggi selama tahun 2019 terdapat pada Kecamatan Kanor. Data BPBD Kabupaten Bojonegoro juga menyebutkan, bahwa banjir di daerah Kecamatan Kanor berasal dari luapan Bengawan Solo dan kiriman air dari Bojonegoro bagian selatan, sehingga menyebabkan wilayah tersebut memiliki intensitas banjir yang tinggi (BNPB, 2019).

Melihat kasus tersebut, puskesmas sebagai fasilitas kesehatan pertama atau dasar dalam suatu daerah harus memiliki sumberdaya dan kompetensi yang cukup dalam kesiapsiagaan bencana. Program tanggap darurat bencana sebagai bagian dari kesiapsiagaan bencana penting dilaksanakan oleh Puskesmas. Hal penting terkait tanggap darurat bencana tersebut antaranya seperti pembentukan panitia, pemenuhan fasilitas, pembuatan SOP tanggap darurat, dan pelatihan mengenai kebakaran. Seluruh program dan upaya tersebut perlu disesuaikan dengan Peraturan Menteri Kesehatan No 52 tahun 2018 tentang K3 di Fasilitas Kesehatan (Nada et al., 2020).

Menurut Undang-Undang Nomor 24 tahun 2007 tentang Penanggulangan Bencana diketahui bahwa kesiapsiagaan bencana merupakan serangkaian kegiatan untuk mengantisipasi bencana. Kegiatan tersebut dilaksanakan melalui pengorganisasian serta melalui langkah pemberdayaan yang harus tepat dan memiliki nilai guna (Pemerintah Republik Indonesia, 2007). Menurut penelitian Baack, 2011 dalam (Wahidah et al., 2016) terdapat 3 faktor yang dapat mempengaruhi kesiapsiagaan tenaga kesehatan dalam menghadapi banjir, yakni perbedaan individu (usia, pengalaman bekerja, pengalaman bencana sebelumnya, dan pengalaman di tempat pengungsian), peraturan diri, dan suasana pelayanan tenaga kesehatan. Kesiapsiagaan bencana pada puskesmas harus memperhatikan beberapa faktor pendukung seperti faktor individu dan faktor organisasi untuk memberikan pelayanan yang tepat. Manajemen bencana yang tepat dalam hal kesiapsiagaan, respon bencana, dan fase pemulihan sangat penting direncanakan secara masif dan terencana mengingat meningkatnya kejadian bencana di seluruh dunia (Putra et al., 2015). Faktor individu menjadi kemungkinan terbesar pemberi pengaruh dalam kesiapsiagaan bencana karena lemahnya kompetensi professional dapat menyebabkan tenaga kesehatan gagal untuk berperan saat bencana (Tatuil et al., 2017). Oleh karena itu, dalam penelitian ini bertujuan untuk menganalisis faktor individu pada tenaga kesehatan yang dapat mempengaruhi kesiapsiagaan Pusat Kesehatan Masyarakat (Puskesmas) di Kabupaten Bojonegoro dalam menghadapi bencana banjir Bengawan Solo.

\section{METODE}

Desain penelitian adalah observasional analitik dengan pendekatan kuantitatif, serta menggunakan rancang bangun penelitian cross-sectional. Puskesmas dalam penelitian ini adalah Puskesmas Kanor karena merupakan puskesmas dengan kerentanan banjir Bengawan Solo tertinggi pada tahun 2019. Populasi penelitian yaitu tenaga kesehatan (dokter, perawat, bidan, teknisi gigi dan mulut, kefarmasian, sanitarian, gizi, analis kesehatan, rekam medis, dan kesehatan masyarakat) di Puskesmas Kanor yang berjumlah 73 orang. Seluruh tenaga kesehatan (dokter, perawat, bidan, teknisi gigi dan mulut, kefarmasian, sanitarian, gizi, analis kesehatan, rekam medis, dan kesehatan masyarakat) baik yang tergabung dalam tim siaga bencana maupun tidak tergabung dalam tim siaga bencana. Besar sampel penelitian sebanyak 51 orang tenaga kesehatan Puskesmas Kanor, dengan teknik pengambilan sampel menggunakan teknik random sampling. Angka besar sampel diperoleh dari perhitungan populasi menggunakan rumus Lemeshow (1997), dengan proporsi target populasi 0,12, standar deviasi sebesar 1,96, CI 95\%, dan derajat ketepatan sebesar 0,05.

Data primer penelitian diperoleh melalui wawancara dengan menggunakan kuesioner. Pengisian kuesioner dengan teknik wawancara dilakukan oleh peneliti kepada tenaga kesehatan Puskesmas Kanor untuk memperoleh data individu. Pengambilan data didampingi langsung oleh penanggung jawab program penanggulangan bencana di puskesmas yang juga merupakan salah satu tenaga kesehatan di Puskesmas Kanor. Data sekunder penelitian didapatkan dari Puskesmas terkait profil dan struktur organisasi tim penanggulangan bencana. Pengisian kuesioner dilakukan dengan didampingi peneliti dengan memperhatikan etika penelitian, meliputi prinsip manfaat, prinsip menghargai hak asasi manusia dan prinsip keadilan.

Variabel independen yang diteliti dalam penelitian ini yaitu faktor individu meliputi usia, tingkat pendidikan, lama kerja, pengalaman penanganan bencana, pelatihan, dan pengetahuan, dan pengaruhnya terhadap kesiapsiagaan puskesmas dalam penanganan bencana sebagai variable dependen. Data yang diperoleh dari hasil penelitian dianalisis secara kuantitatif dengan pengolahan data yang dilakukan secara computerize. Uji validitas instrumen dilakukan pada 10 responden tenaga kesehatan. Pada penelitian ini uji validitas memiliki r- 
hitung lebih dari r-tabel = 0,63 didapatkan hasil valid pada nilai signifikasi 5\%. Penelitian ini juga telah lolos uji etik di Fakultas Kedokteran Gigi Universitas Airlangga dengan nomor sertifikat 095/HRECC/FODM/III/2020.

Seluruh data faktor individu diperoleh dari hasil kuesioner yang kemudian dikategorikan dengan mengacu pada penelitian-penelitian sebelumnya. Faktor usia dikategorikan menjadi 2 kategori (20-35; 36-60), tingkat pendidikan menjadi 2 kategori (D3 dan S1) sesuai dengan pendidikan mayoritas petugas kesehatan, lama bekerja menjadi 4 kategori ( $\leq 1$ tahun; > 1-5 tahun; 6-10 tahun; >10 tahun), pengalaman bencana sebelumnya dan pelatihan tentang manajemen bencana (ya/tidak), dan pengetahuan menjadi 3 kategori adopsi berdasarkan penelitian Arikuto, 2010 (Baik (76\%-100\%); Cukup (56\%-75\%); Kurang (<56\%)). Pada faktor kesiapsiagaan, disesuaikan dengan indikator dari LIPI-UNESCO/ ISDR 2006 yang meliputi, kebijakan dan panduan, rencana tanggap darurat, sistem peringatan dini, dan mobiltas sumber daya dengan menyesuaikan Skala Likert dengan kategori sangat siap (total nilai 80-100), siap (65-79), hampir siap (55-64), kurang siap (40-54), dan belum siap $(<40)$ sebagai cara pengukuran.

Analisis faktor yang mempengaruhi kesiapsiagaan puskesmas menggunakan uji pengaruh sesuai dengan skala data. Analisis pengaruh dilakukan dengan uji statistik untuk mengetahui pengaruh antar variabel. Uji signifikan dilakukan pada taraf alpha $=0,05$. Instrumen reliabel karena nilai alpha lebih besar dari r-tabel $(0,63)$. Uji signifikansi setiap variabel dilakukan dengan menggunakan uji regresi logistik ordinal melalui bantuan aplikasi SPSS. Hasil menunjukkan bermakna apabila nilai OR tidak melewati angka 1 dalam rentang atas dan bawah.

\section{HASIL DAN PEMBAHASAN}

\section{Karakteristik responden}

Berdasarkan Tabel 1 dapat diketahui bahwa responden di Puskesmas Kanor sebagian besar berjenis kelamin perempuan (68.60\%). Sebagian besar responden berprofesi sebagai bidan (49\%).

Tabel 1. Distribusi ketegori karakteristik responden Puskesmas Kanor di Kabupaten Bojonegoro menurut jenis kelamin dan profesi.

\begin{tabular}{lll}
\hline Variabel & $\mathrm{n}$ & $\%$ \\
\hline Jenis Kelamin & & \\
Laki-laki & 16 & 31,40 \\
Perempuan & 35 & 68,60 \\
Profesi & & \\
$\quad$ Dokter & 1 & 2,00 \\
Perawat & 18 & 35,30 \\
Bidan & 25 & 49,00 \\
Nutrisionis & 1 & 2,00 \\
Analis medis & 1 & 2,00 \\
Perawat gigi & 1 & 2,00 \\
Rekam Medik & 1 & 2,00 \\
Ahli kesehatan masyarakat & 1 & 2,00 \\
Asisten apoteker & 1 & 2,00 \\
Sanitarian & 1 & 2,00 \\
\hline Total & 51 & 100,00 \\
\hline
\end{tabular}

\section{Faktor individu}

Berdasarkan Tabel 2 dapat diketahui bahwa responden di Puskesmas Kanor, sebagian besar berusia 35-60 tahun, tingkat pendidikan kuliah S1, lama kerja >10 tahun, sebanyak 26 orang tidak memiliki pengalaman penanganan bencana sebelumnya. Sebagian besar pernah mendapat pelatihan manajemen bencana sebanyak 32 orang, dan memiliki pengetahuan yang cukup baik sebanyak 25 orang. Hasil nilai signifikansi uji regresi logistik ordinal faktor individu dan kesiapsiagaan yang didapatkan yakni, usia (AOR 4,11;95\%CI=1,27-13,35), tingkat pendidikan ( $\mathrm{AOR} 14,23 ; 95 \% \mathrm{CI}=1,67-121,3$ ), lama bekerja ( $\mathrm{AOR} 3,12 ; 95 \% \mathrm{CI}=0,90-10,76$ ), pengalaman bencana sebelumnya (AOR 1,14; 95\% CI=0,16-2,46), pelatihan (AOR 2,45; 95\%CI=0,74-8,07), dan pengetahuan (AOR 2,00; 95\% CI=0,65-6,15), yang mana selengkapnya telah disajikan pada tabel 2 dan dijelaskan pada bab pembahasan.

\section{PEMBAHASAN}

\section{Pengaruh usia dengan kesiapsiagaan menghadapi bencana banjir}

Penelitian ini menunjukkan bahwa faktor individu yaitu usia memiliki pengaruh terhadap kesiapsiagaan puskesmas dalam menghadapi bencana banjir Bengawan. Hasil menunjukkan OR sebesar 4,11 dan rentang batas 
bawah dengan batas atas yaitu $(95 \% \mathrm{CI}=1,27-13,35)$ sehingga bermakna bahwa seseorang yang memiliki usia semakin tua tersebut maka lebih siap terkait kesiapsiagaan bencana 4,11 kali lebih besar daripada seseorang memiliki usia muda. Penelitian ini didukung oleh penelitian dari Eka Septiana dan Hudzaifah 2019, yang menyebutkan bahwa variabel usia memiliki hubungan signifikan dengan kesiapsiagaan bencana, dengan $p=0,03$ $<0,05$. Nilai korelasi positifnya menunjukkan bahwa semakin tua usia atau usia maka perawat akan semakin siaga (Septiana dan Fatih, 2019). Mendukung pernyataan tersebut, dalam penelitian Heti Aprilin 2018 disebutkan bahwa usia dapat mempengaruhi kesiapsiagaan bencana dikarenakan memiliki pengaruh yang cukup signifikan terhadap perilaku individu. Penelitian tersebut menjelaskan bahwa responden hampir tiap tahun mengalami kondisi bencana banjir, hal itu secara tidak langsung memotivasi mereka untuk bersosialisasi dengan lingkungan. Hal itu mejadi bukti bahwa semakin dewasa individu, maka semakin berpengalaman dalam kesiapsiagaan bencana banjir (Aprilin et al., 2018).

Hal ini berbeda dengan penelitian Wahidah et al (2016) tentang faktor yang mempengaruhi kesiapsiagaan perawat dalam menghadapi bencana banjir di Kecamatan Gumukmas Kabupaten Jember. Penelitian tersebut mendapatkan hasil faktor umum memiliki $\mathrm{p}$ value 0,99 atau $\mathrm{p}>0,25$, yang berarti bahwa tidak ada pengaruh signifikan antara faktor usia dengan kesiapsiagaan bencana. Hal itu mungkin disebabkan karena jumlah responden penelitian tersebut yang sangat sedikit dan kurang heterogen, yakni hanya 16 orang dengan kelompok usia 26-35 tahun. Hal itu membuat faktor tersebut kurang kuat dalam memberikan kesimpulan hasil (Wahidah et al., 2016).

Tabel 2. Distribusi ketegori faktor individu responden Puskesmas Kanor di Kabupaten Bojonegoro menurut usia, tingkat pendidikan, lama kerja, pengalaman penanganan bencana, pelatihan, dan pengetahuan.

\begin{tabular}{|c|c|c|c|c|c|c|c|c|c|c|c|c|c|c|}
\hline \multirow{3}{*}{ Variabel } & \multicolumn{10}{|c|}{ Kesiapsiagaan Bencana di Puskesmas } & & & \multirow{3}{*}{ p-value } & \multirow{3}{*}{$\begin{array}{c}\text { OR } \\
(95 \% \mathrm{CI})\end{array}$} \\
\hline & \multicolumn{2}{|c|}{$\begin{array}{c}\text { Belum } \\
\text { Siap } \\
\end{array}$} & \multicolumn{2}{|c|}{$\begin{array}{c}\text { Kurang } \\
\text { Siap }\end{array}$} & \multicolumn{2}{|c|}{$\begin{array}{c}\text { Hampir } \\
\text { Siap }\end{array}$} & \multicolumn{2}{|c|}{ Siap } & \multicolumn{2}{|c|}{$\begin{array}{c}\text { Sangat } \\
\text { Siap }\end{array}$} & \multicolumn{2}{|c|}{ Jumlah } & & \\
\hline & $\mathrm{n}$ & $\%$ & $\mathrm{n}$ & $\%$ & $\mathrm{n}$ & $\%$ & $\mathrm{n}$ & $\%$ & $\mathrm{n}$ & $\%$ & $\mathrm{n}$ & $\%$ & & \\
\hline \multicolumn{15}{|c|}{ Usia (Tahun) } \\
\hline $20-35$ & 10 & 40,0 & 5 & 20,0 & 3 & 12,0 & 0 & 0,00 & 7 & 28,0 & 25 & 100 & \multirow{2}{*}{$0,00 *$} & 4,11 \\
\hline $35-60$ & 7 & 28,0 & 2 & 7,69 & 1 & 3,84 & 7 & 26,92 & 9 & 34,61 & 26 & 100 & & $(1,27-13,35)$ \\
\hline \multicolumn{15}{|c|}{ Tingkat Pendidikan } \\
\hline D3 & 8 & 66,6 & 1 & 8,3 & 2 & 16,6 & 0 & 0 & 1 & 8,3 & 12 & 100,0 & \multirow{2}{*}{$0,01 *$} & 14,23 \\
\hline $\mathrm{S} 1$ & 9 & 23,1 & 6 & 15,4 & 2 & 5,1 & 7 & 17,9 & 15 & 38,5 & 39 & 100,0 & & $(1,67-121,3)$ \\
\hline \multicolumn{15}{|c|}{ Lama Bekerja (Tahun) } \\
\hline$\leq 1$ & 3 & 60,0 & 2 & 40,0 & 0 & 0,00 & 0 & 0,00 & 0 & 0,00 & 5 & 100 & \multirow{4}{*}{0,59} & \multirow{4}{*}{$\begin{array}{l}3,12 \\
(0,90-10,76)\end{array}$} \\
\hline$>1-5$ & 4 & 30,8 & 1 & 7,7 & 3 & 23,0 & 0 & 0,00 & 5 & 38,5 & 13 & 100 & & \\
\hline$>5-10$ & 4 & 57,1 & 0 & 0,0 & 0 & 0,00 & 0 & 0,00 & 3 & 42,8 & 7 & 100 & & \\
\hline$>10$ & 6 & 23,1 & 4 & 15,4 & 1 & 3,8 & 7 & 26,9 & 8 & 30,8 & 26 & 100 & & \\
\hline \multicolumn{15}{|c|}{ Pengalaman Bencana } \\
\hline Tidak & 14 & 53,8 & 4 & 15,4 & 3 & 11,5 & 1 & 3,8 & 4 & 15,4 & 26 & 100 & \multirow{2}{*}{0,09} & 1,14 \\
\hline $\mathrm{Ya}$ & 3 & 12,0 & 3 & 12,0 & 1 & 4,0 & 6 & 24,0 & 12 & 48,0 & 25 & 100 & & $(0,16-2,46)$ \\
\hline \multicolumn{15}{|l|}{ Pelatihan } \\
\hline Tidak & 6 & 31,6 & 5 & 26,3 & 2 & 10,5 & 2 & 10,5 & 4 & 21,0 & 19 & 100 & \multirow{2}{*}{0,45} & 2,45 \\
\hline $\mathrm{Ya}$ & 11 & 34,4 & 2 & 6,2 & 2 & 6,2 & 5 & 15,6 & 12 & 37,5 & 32 & 100 & & $(0,74-8,07)$ \\
\hline \multicolumn{15}{|c|}{ Pengetahuan } \\
\hline Baik & 2 & 100,0 & 0 & 0,0 & 0 & 0,00 & 0 & 0,00 & 0 & 0,00 & 2 & 100 & \multirow{3}{*}{0,32} & \multirow{3}{*}{$\begin{array}{l}2,00 \\
(0,65-6,15)\end{array}$} \\
\hline Cukup & 7 & 28,0 & 6 & 24,0 & 2 & 8,0 & 4 & 16,0 & 6 & 24,0 & 25 & 100 & & \\
\hline Kurang & 8 & 33,3 & 1 & 4,2 & 2 & 8,3 & 3 & 12,5 & 10 & 41,7 & 24 & 100 & & \\
\hline Total & 17 & 33,33 & 7 & 13,73 & 4 & 7,84 & 7 & 13,73 & 16 & 31,37 & 51 & $100 \%$ & & \\
\hline
\end{tabular}

\section{Pengaruh tingkat pendidikan dengan kesiapsiagaan menghadapi bencana banjir}

Penelitian ini menunjukkan bahwa kesiapsiagaan puskesmas dalam menghadapi bencana bencana banjir Bengawan Solo dipengaruhi secara signifikan oleh tingkat pendidikan petugas kesehatan. Hasil menunjukkan OR sebesar 14,23 dan rentang batas bahwa dengan batas atas yaitu $(95 \% \mathrm{CI}=1,67-121,3)$ sehingga bermakna bahwa seseorang yang memiliki pendidikan S1 lebih siap terkait kesiapsiagaan bencana 14,23 kali lebih besar daripada seseorang dengan pendidikan D3. Hal ini sejalan dengan penelitian Yava dkk, 2013 yang menyatakan bahwa tenaga kesehatan dengan tingkat pendidikan gelar master atau lebih tinggi dan tenaga kesehatan dengan gelar sarjana muda memiliki nilai signifikansi lebih tinggi dari tenaga kesehatan lulusan sekolah menengah atas; tenaga kesehatan yang telah mengambil program pascasarjana manajemen memiliki signifikansi lebih tinggi daripada mereka yang tidak; demikian pula, tenaga kesehatan yang membaca buku-buku atau jurnal tentang bidang disiplin ilmunya memiliki signifikansi lebih tinggi daripada yang lain (Yava A. et al., 2013). 
Kualifikasi pendidikan memainkan peran penting dalam kemauan petugas kesehatan untuk berpartisipasi dalam bencana dan tanggap darurat (Al-Hunaishi et al., 2019). Pada penelitian Sultan dkk, 2020, kesiapan petugas dalam penanggulangan bencana di wilayahnya menunjukkan bahwa mereka yang memiliki pengetahuan pendidikan yang lebih tinggi lebih banyak percaya diri untuk bertindak dalam keadaan darurat dan bencana (Sultan et al., 2020).

\section{Pengaruh lama bekerja dengan kesiapsiagaan menghadapi bencana banjir}

Pada penelitian ini lama bekerja tidak memiliki pengaruh terhadap kesiapsiagaan puskesmas dalam menghadapi bencana banjir Bengawan Solo (AOR 3,12; 95\%CI=0,90-10,76). Sejalan dengan hal itu, penelitian Bakri et al 2020 juga menunjukkan tidak ada perbedaan yang bermakna antara kesiapsiagaan Puskesmas dengan faktor lama pengalaman kerja tenaga kesehatannya (Bakri et al., 2020).

Penelitian lain menunjukkan hal yang berbeda, Wahidah et al., 2016 yang menyebutkan bahwa lama kerja dapat mempengaruhi kesiapsiagaan perawat dalam menghadapi bencana banjir sebesar 62,5\% (Wahidah et al., 2016). Selain itu, pada penelitian Eka Septiana et al., 2019 juga mendapatkan hasil hubungan signifikan antara lama kerja perawat dengan kesiapsiagaan bencana, yakni $p=0,03 p<0,05$ (Septiana dan Fatih, 2019). Perbedaan dari hasil yang didapatkan peneliti dengan beberapa penelitian lain tersebut, dimungkinkan karena petugas kesehatan juga perlu meningkatkan kesiapsiagaan tidak hanya diukur berdasarkan lama bekerja, namun juga dengan berfokus pada faktor-faktor lain yang dapat mempengaruhinya, seperti peraturan diri dan suasana di pelayanan kesehatan (Wahidah et al., 2016).

\section{Pengaruh pengalaman bencana sebelumnya dengan kesiapsiagaan menghadapi bencana banjir}

Pada tabel 2, diketahui bahwa pengalaman bencana sebelumnya pada petugas kesehatan tidak memiliki pengaruh terhadap kesiapsiagaan puskesmas dalam menghadapi bencana banjir Bengawan Solo (AOR 1,14; 95\% CI=0,16-2,46). Sejalan dengan penelitin Eka Septiana et al., 2019, pengalaman bencana sebelumnya maupun pengalaman bencana di tempat pengungsian tidak memiliki korelasi dengan kesiapsiagaan perawat puskesmas Bandung dalam menghadapi bencana banjir ( $r=0,256, r=0,256)$ (Septiana dan Fatih, 2019). Pada penelitian dari Kim Usher et al., 2015 di wilayah Asia-Pasifik dan Wahidah et al., 2016 di Kecamatan Gumukmas, Kabupaten Jember juga mendapatkan hasil serupa yakni tidak menunjukkan adanya hubungan signifikan antara pengalaman bencana sebelumnya dengan kesiapsiagaan perawat puskesmas dalam menghadapi bencana (Usher et al., 2015; Wahidah et al., 2016).

Hal tersebut dimungkinkan karena pengalaman terkait kesiapsiagaan dalam penanganan bencana dapat dipengaruhi oleh beberapa faktor, seperti lama keterlibatan, perbedaan seseorang dalam batas waktu yang cukup untuk dipakainya dalam memahami tugas suatu pekerjaan dan bagaimana hasil dari pekerjaan tersebut, serta tingkat pengetahuan dan keterampilan yang dimilikinya. Pada penelitian Wirawan et al., 2019 diketahui terdapat pengaruh yang signifikan tingkat pendidikan dan pengalaman kerja terhadap kinerja pada karyawan. Teori oleh Usman 2011, yang dipakai dalam penelitian Wirawan et al, 2019 juga memaparkan jika tinggi rendahnya tingkat pendidikan seseorang akan memberikan pengaruh terhadap kinerja karyawan (Wirawan et al., 2019). Hal itu berarti seseorang dengan pengalaman yang banyak belum tentu lebih siap siaga dalam menghadapi bencana banjir dibandingkan dengan seseorang yang pengalamannya sedikit, serta variabel tingkat pendidikan lebih dominan untuk mempengaruhinya.

\section{Pengaruh pelatihan tentang manajemen bencana dengan kesiapsiagaan menghadapi bencana banjir}

Pada hasil juga didapatkan bahwa salah satu variabel faktor individu yaitu pelatihan tentang manajemen bencana tidak memiliki pengaruh terhadap kesiapsiagaan puskesmas dalam menghadapi bencana banjir Bengawan Solo (AOR 2,45; 95\%CI=0,74-8,07). Hasil tersebut sejalan dengan penelitian Bakri et al 2020, bahwa tidak ada hubungan bermakna antara frekuensi pelatihan bencana dengan kesiapsiagaan tenaga kesehatan puskesmas dalam penanggulangan bencana banjir di Kecamatan Manggala Kota Makassar (Bakri et al., 2020).

Hal itu tidak sejalan dengan penelitian Novria et al., 2019 yang mendapatkan pelatihan sebagai faktor dominan terhadap kesiapsiagaan bidan dalam menghadapi bencana Gempa dan Tsunami di Puskesmas kota Padang tahun 2018 dengan nilai $\mathrm{p}=0,00, \mathrm{p}<0,05$ (Hesti et al., 2019). Begitu juga pada penelitian yang dilakukan oleh Fitriani dan Patmiati (2019) di Desa Nglurup yang menyatakan bahwa terdapat pengaruh penyuluhan kesehatan tentang kesiapsiagaan terhadap sikap masyarakat dalam mengatasi masalah kesehatan akibat bencana. Namun bencana dalam penelitian itu adalah tanah longsor (Fitriani dan Patmiati, 2019). Perbedaan tersebut dimungkinkan karena dalam penelitian ini tingkat pendidikan memberikan pengaruh lebih besar daripada pelatihan bencana yakni dengan nilai signifikansi sebesar 0,01 . Hal itu dikarenakan, tingkat pendidikan dapat mempengaruhi tingkat pemahaman individu ketika mengikuti pelatihan kesiapsiagaan bencana.

Penelitian Adzhani et al (2016) menyebutkan jika dalam melaksanakan pelatihan simulasi tanggap darurat diperlukan 3 (tiga) tahap yaitu tahap persiapan, tahap prapelaksanaan, dan tahap pelaksanaan (Adzhani et al., 2016). Memberikan keterampilan dan pelatihan terkait kesiapsiagaan bencana dapat mempengaruhi kualitas pekerja, meliputi pengetahuan, sikap, dan perilaku seseorang. Memberikan pelatihan keterampilan seperti 
pelatihan perencanaan bencana, pertolongan pertama, dan pelatihan bantuan hidup dasar dapat meningkatkan kesiapsiagaan tenaga kesehatan dalam menghadapi bencana banjir. Pelatihan manajemen bencana sangat diperlukan untuk meningkatkan tenaga kesehatan dalam kesiapsiagaan bencana. Hal ini dapat membantu tenaga kesehatan dalam menyiapkan diri pada saat pra bencana, tanggap darurat bencana, dan pasca bencana. Hal tersebut dapat menjadikan tenaga kesehatan mampu melakukan pertolongan pada korban, khususnya pada kelompok rentan saat pelaksanaan tahap pasca bencana (Adnan \& Dampung, 2020; Widayatun \& Fatoni, 2013).

\section{Pengaruh tingkat pengetahuan dengan kesiapsiagaan menghadapi bencana banjir}

Dalam penelitian ini, tingkat pengetahuan responden tentang kesiapan bencana banjir sebagian besar responden $(47,1 \%)$ memiliki pengetahuan yang kurang dan yang memiliki pengetahuan baik hanya $3,9 \%$ saja. Hal ini tidak serupa dengan penelitian Devi Ashalata (2015) yang menghasilkan data, sebesar 58\% responden memiliki pengetahuan yang cukup tentang kesiapan gempa. Hal tersebut berbeda pula dengan hasil penelitian Taghzadeh et al (2016) yang 28,3\% respondennya memiliki pengetahuan cukup tentang kesiapsiagaan menghadapi bencana (Devi dan Sharma, 2015; Taghizadeh et al., 2016).

Pengetahuan tenaga kesehatan terhadap kesiapsiagaan bencana dalam penelitian ini, tidak memiliki pengaruh terhadap kesiapsiagaan puskesmas dalam menghadapi bencana banjir Bengawan Solo. Hasil tersebut bertolak belakang dengan penelitian lain yang menyatakan bahwa terdapat hubungan signifikan antara tingkat pengetahuan dengan kesiapsiagaan dalam mengadapi bencana (Hesti et al., 2019). Begitu juga pada penelitian Kurniawati 2019, bahwa terdapat pengaruh antara pengetahuan dengan perilaku kesiapsiagaan bencana. Menurutnya, semakin bertambah pengetahuan maka akan memicu semakin tingginya perilaku kesiapsiagaan (Kurniawati dan Suwito, 2019). Selain itu pengetahuan kebencanaan dan sikap masyarakat juga memiliki pengaruh positif terhadap kesiapsiagaan menghadapi bencana longsor (Adiwijaya, 2017).

Dalam penelitian Simandalahi et al (2019) pendidikan kesehatan terutama terkait kesehatan dalam bencana yang diberilakan melalui beberapa metode seperti, ceramah, diskusi, game, dan simulasi kepada semua orang terutama tenaga kesehatan dikatakan penting, karena hal tersebut dapat meningkatkan pengetahuannya (Simandalahi, Alwi, et al., 2019; Simandalahi, Apriyeni, et al., 2019). Mendukung hal itu, penelitian Lindawati (2017) menyebutkan jika orang yang berpengetahuan tinggi, akan memiliki kesiapsiapsiagaan 4 kali lebih baik ketimbang orang yang berpengetahuan rendah (Lindawati \& Wasludin, 2017).

Penelitian ini mendapat hasil yang berbeda dengan penelitian lain dikarenakan, jika adanya pengetahuan tinggi tanpa diimbangi kesadaran dan kemampuan yang cukup dalam melaksanakan manajemen bencana, maka tidak akan mempengaruhi kesiapsiagaan petugas kesehatan dalam menghadapi bencana banjir. Hasil OR 14,23 yang tidak melewati angka 1 dalam rentang batas atas dan batas bawahnya pada hubungan tingkat pendidikan dengan kesiapsiagaan bencana petugas kesehatan Pukesmas Kanor, yang mana memperkuat hasil penelitian bahwa tingkat pendidikan lebih berpengaruh pada seseorang untuk memahami Standart Operating Procedure (SOP) dalam kesiapsiagaan bencana banjir di daerah mereka masing-masing daripada tingkat pengetahuannya.

Impact yang dapat diberikan dalam penelitian ini adalah untuk memperbaiki kebijakan dalam kesiapsiagaan bencana pada Puskesmas Kanor. Kebijakan tersebut dapat berupa pembentukan struktur tim kesiapsiagaan bencana dengan melibatkan kader desa sehingga dapat memaksimalkan kesiapsiagaan bencana dari lingkup terkecil.

Kelebihan dalam penelitian ini adalah berfokus pada faktor individu sehingga dapat menilai pengaruh profesionalitas petugas dengan kesiapsiagaan bencana, dengan begitu puskesmas dapat memaksimalkan faktor individu secaraefektif. Kekurangan dalam penelitian ini adalah belum memasukkan elemen lain sehingga dimungkinkan terdapat faktor lain yang lebih berpengaruh dalam kesiapsiagaan bencana.

\section{KESIMPULAN}

Berdasarkan hasil penelitian dan pembahasan sebagaimana telah dikemukakan dapat disimpulkan bahwa, faktor individu tenaga kesehatan yang meliputi usia dan tingkat pendidikan memiliki pengaruh terhadap kesiapsiagaan puskesmas dalam menghadapi bencana. Pada faktor individu tenaga kesehatan yang lain, meliputi lama bekerja, pengetahuan, pelatihan tentang manajemen bencana, dan pengalaman bencana sebelumnya tidak memiliki pengaruh terhadap kesiapsiagaan puskesmas dalam menghadapi bencana banjir Bengawan Solo.

\section{ACKNOWLEDGEMENT}

Seluruh penulis yang tercantum dalam artikel berpartisipasi secara aktif dalam artikel ini. Penulis bertanggung jawab secara penuh atas isi tulisan, termasuk dalam persiapan, penulisan draf, penelitian pemilihan desain, analisis, dan revisi artikel. SF: persiapan, konseptualisasi, metodologi, perangkat lunak, dan kurasi data. UMH: penulisan draft, analisis, pengeditan, dan revisi artikel. SH: supervisi dan validasi. 


\section{REFERENSI}

Adiwijaya, C. (2017). Pengaruh Pengetahuan Kebencanaan dan Sikap Masyarakat Terhadap Kesiapsiagaan Menghadapi Bencana Tanah Longsor (Studi di Kelurahan Lawanggintung, Kecamatan Bogor Selatan, Kota Bogor). Jurnal Prodi Manajemen Bencana.

Adnan, J., \& Dampung, V. M. (2020). Penanggulangan Masalah Kesehatan dalam Kondisi Pasca Longsor di Desa Samaenre, Kecamatan Mallawa, Kabupaten Maros. INDRA: Jurnal Pengabdian Kepada Masyarakat. https://doi.org/10.29303/indra.v1i1.7

Adzhani, F., Widjasena, B., \& Kurniawan, B. (2016). Analisis Implementasi Manajemen Pelatihan Kesiapan Petugas Tanggap Darurat dalam Menghadapi Bencana Gempa Bumi Pada Gedung Instalasi Rawat Inap I (Irna I) Di RSUP Dr. Sardjito Yogyakarta. Jurnal Kesehatan Masyarakat (e-Journal).

Al-Hunaishi, W., Hoe, V. C. W., \& Chinna, K. (2019). Factors associated with healthcare workers willingness to participate in disasters: A cross-sectional study in Sana'a, Yemen. BMJ Open. https://doi.org/10.1136/bmjopen-2019-030547

Aprilin, H., Haksama, S., \& Makhfludi. (2018). Kesiapsiagaan Sekolah Terhada Potensi Bencana Banjir di SDN Gebangmalang Kecamatan Mojoanyar Kabupaten Mojokerto. Jurnal Biosains Pascasarjana, 20(2), 133145.

Bakri, H., Arif, S. K., \& Amin, H. (2020). Kesiapsiagaan Tenaga Kesehatan Puskesmas dalam Penanggulangan Bencana Banjir di Kecamatan Manggala Kota Makassar Tahun 2019. Media Kesehatan Politeknik Kesehatan Makassar, 15(1), 59. https://doi.org/10.32382/medkes.v15i1.1341

BNPB. (2019). Data \& Informasi Bencana Indonesia. DIBI. http://dibi.bnpb.go.id/

Devi, A., \& Sharma, D. (2015). Awareness on earthquake preparedness: A key to safe life. International Journal of Nursing Research and Practice, 2(2).

Dinar, D. A. P., Sarino, S., \& Agus, L. Y. (2019). Database Structure of Land Allocation Management Information System for Estimating Run-Off in Watersheds. International Journal of GEOMATE Geotec. Const. Mat \& Env, 17(59), 34-42. https://doi.org/10.21660/2019.59.4710

Fitriani, E. T., \& Patmiati, F. I. (2019). Pengaruh Pendidikan Kesehatan Tentang Kesiapsiagaan Masyarakat Terhadap Sikap Masyarakat dalam Mengatasi Masalah Kesehatan Akibat Bencana Tanah Longsor. Jurnal Keperawatan Jiwa. https://doi.org/10.26714/jkj.7.1.2019.71-78

Hesti, N., Yetti, H., \& Erwani, E. (2019). Faktor-Faktor yang berhubungan dengan Kesiapsiagaan Bidan dalam Menghadapi Bencana Gempa dan Tsunami di Puskesmas Kota Padang. Jurnal Kesehatan Andalas, 8(2), 338. https://doi.org/10.25077/jka.v8i2.1010

Irvani, \& Gunawan, I. (2015). Studi Pendahuluan Potensi Bencana Alam ( Geo-Disaster ) Di Pulau Bangka. Promine, 3(2), 1-9.

Kurnia Fitriningsih. (2014). Hubungan Tingkat Pendidikan formal dengan Kesiapsiagaan dalam Menghadapi Bencana Gempa Bumi Masyarakat Desa Jabung Kecamatan Gantiwarno Kab Klaten. In Fakultas Keguruan dan Ilmu Pendidikan Universitas Muhammadiyah Surakarta.

Kurniawati, D., \& Suwito, S. (2019). Pengaruh Pengetahuan Kebencanaan Terhadap Sikap Kesiapsiagaan dalam Menghadapi Bencana Pada Mahasiswa Program Studi Pendidikan Geografi Universitas Kanjuruhan Malang. JPIG (Jurnal Pendidikan Dan Ilmu Geografi). https://doi.org/10.21067/jpig.v2i2.3507

Lindawati, L., \& Wasludin, W. (2017). Hubungan Pengetahuan dan Sikap Tentang Bencana Banjir Terhadap Kesiapsiagaan Dalam Kesehatan Pada Masyarakat Rw 05 Rt 01 dan Rt 03 Kelurahan Gondrong Kota Tangerang. Jurnal Medikes (Media Informasi Kesehatan). https://doi.org/10.36743/medikes.v4i2.86

Maryanti, S., Lestari, E., Putri, W., Wardani, A. R., \& Haris, F. (2017). Hubungan Tingkat Pendidikan Masyarakat Terhadap Kesiapsiagaan Bencana Tanah Longsor di Kelurahan Giritirto Kecamatan Wonogiri. Prosiding Seminar Nasional Geografi UMS 2017 : ISBN: 978-602-361-072-3, S 540907024, 1-93.

Nada, F. Q., Denny, H. M., \& Setyaningsih, Y. (2020). Implementasi Keselamatan dan Kesehatan Kerja di Puskesmas: Studi Kasus di Kabupaten Pekalongan. Jurnal Manajemen Kesehatan Indonesia. https://doi.org/10.14710/jmki.8.2.2020.98-104

Pemerintah Republik Indonesia. (2007). Undang-Undang Nomor 24 Tahun 2007 tentang Penanggulangan Bencana. In Pemerintah Republik Indonesia.

Purwantara, S. (2015). Dampak Pengembangan Permukiman Terhadap Air Tanah di Wilayah Yogyakarta dan Sekitarnya. Geo Edukasi, 4(1). jurnalnasional.ump.ac.id/index.php/GeoEdukasi/article/view/535

Putra, A., Juwita, R., Risna, Alfiandi, R., Arnita, Y., Iqbal, M., \& Ervina. (2015). Peran Dan Kepemimpinan Perawat Dalam Manajemen Bencana Pada Fase Tanggap Darurat. Idea Nursing Journal.

Sastrodiharjo, S. (2012). Upaya Mengatasi Masalah Banjir Secara Menyeluruh. Mediatama Saptakarya.

Septiana, M. E., \& Fatih, H. Al. (2019). Hubungan Karakteristik Individu dengan Kesiapsiagaan Perawat Puskesmas. Jurnal Ilmiah Kesehatan Keperawatan, 15(1), 1-6. https://doi.org/10.26753/jikk.v15i1.275

Simandalahi, T., Alwi, N. P., Sari, I. K., \& Prawata, A. H. M. (2019). Edukasi Kesiapsiagaan Bencana Gempa Bumi Melalui Pendidikan Kesehatan. Jurnal Abdimas Saintika. 
Simandalahi, T., Apriyeni, E., \& Pardede, R. (2019). Pengaruh Pendidikan Kesehatan Terhadap Pengetahuan Siswa Tentang Kesiapsiagaan Bencana Gempa Bumi. Jurnal Kesehatan Medika Saintika. https://doi.org/10.30633/jkms.v10i1.314

Sulaeman, A., Suhartanto, E., \& Sumiadi, S. (2017). Analisis Genangan Banjir Akibat Luapan Bengawan Solo untuk Mendukung Peta Risiko Bencana Banjir di Kabupaten Bojonegoro. Jurnal Teknik Pengairan. https://doi.org/10.21776/ub.pengairan.2017.008.02.1

Sultan, M. A. S., Khorram-Manesh, A., Carlström, E., Sørensen, J. L., Al Sulayyim, H. J., \& Taube, F. (2020). Nurses' readiness for emergencies and public health challenges-The case of Saudi Arabia. Sustainability (Switzerland). https://doi.org/10.3390/SU12197874

Taghizadeh, Z., Khoshnam Rad, M., \& Kazemnejad, A. (2016). Midwives' Professional Competency for Preventing Neonatal Mortality in Disasters. Health in Emergencies \& Disasters Quarterly, 1(3). https://doi.org/10.15412/J.HDQ.09010306

Tatuil, S., Mandagi, C. K. F., \& Sulaemana, E. (2017). Kajian Peran Tenaga Keshatan dalam Kesiapsiagaan Bencana Banjir di Wilayah Kerja Puskesmas Tumiting Kota Manado. E Journal Health.

Usher, K., Mills, J., West, C., Casella, E., Dorji, P., Guo, A., Koy, V., Pego, G., Phanpaseuth, S., Phouthavong, O., Sayami, J., Lak, M. S., Sio, A., Ullah, M. M., Sheng, Y., Zang, Y., Buettner, P., \& Woods, C. (2015). Cross-sectional survey of the disaster preparedness of nurses across the Asia-Pacific region. Nursing and Health Sciences. https://doi.org/10.1111/nhs.12211

Wahidah, D. A., Rondhianto, \& Hakam, M. (2016). Faktor - Faktor yang Mempengaruhi Kesiapsiagaan Perawat dalam Menghadapi Bencana Banjir di Kecamatan Gumukmas Kabupaten Jember ( Factors Influencing Nurse Preparedness in the Face of Flooding in Gumukmas District in Jember ). E-Jurnal Pustaka Kesehatan, 4(3), 568-574. https://jurnal.unej.ac.id/index.php/JPK/article/view/6166

Wahyudi, M., Azikin, R., \& Rahim, S. (2019). Manajemen Penanggulangan Banjir di Kelurahan Panccekrang Kota Makassar. Jurnal Administrasi Publik, April 2019.

Widayatun, \& Fatoni, Z. (2013). Permasalahan Kesehatan Dalam Kondisi Bencana: Peran Petugas Kesehatan dan Partisipasi Masyarakat. Jurnal Kependudukan Indonesia.

Wirawan, K. E., Bagia, I. W., \& Susila, G. P. A. J. (2019). Pengaruh Tingkat Pendidikan dan Pengalaman Kerja Terhadap Kinerja Karyawan. Bisma: Jurnal Manajemen, 5(1), 60-67. https://ejournal.undiksha.ac.id/index.php/BISMA-JM/article/view/21991/13608

Yava A., Cicek, H., Tosun, N., Ozcan, C., Yildiz, D., \& Dizer, B. (2013). Knowledge and Attitudes of Nurses about Pain Management in Turkey. International Journal of Caring Sciences, 6(3), 494-505.

Yustiani, Y. M., Wahyuni, S., \& Kadir, A. A. A. (2019). IDENTIFIKASI NILAI LAJU DEOKSIGENASI DI DAERAH PADAT PENDUDUK (STUDI KASUS SUNGAI CICADAS, BANDUNG). Journal of Community Based Environmental Engineering Management. https://doi.org/10.23969/jcbeem.v3i1.1496 